\title{
RESEARCH
}

Open Access

\section{Mesenchymal stromal cells protect against vascular damage and depression-like behavior in mice surviving cerebral malaria}

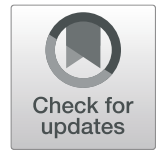

\author{
Maiara N. Lima', Helena A. Oliveira', Paula M. Fagundes' ${ }^{1}$, Vanessa Estato ${ }^{1}$, Adriano Y. O. Silva', \\ Rodrigo J. R. X. Freitas', Beatriz A. B. R. Passos ${ }^{1}$, Karina S. Oliveira ${ }^{1}$, Camila N. Batista ${ }^{1}$, Adriana L. Vallochi', \\ Patricia R. M. Rocco ${ }^{2,3}$, Hugo C. Castro-Faria-Neto ${ }^{1,4}$ and Tatiana Maron-Gutierrez ${ }^{14^{*}}$ (i)
}

\begin{abstract}
Background: Malaria is one of the most critical global infectious diseases. Severe systemic inflammatory diseases, such as cerebral malaria, lead to the development of cognitive and behavioral alterations, such as learning disabilities and loss of memory capacity, as well as increased anxiety and depression. The consequences are profound and usually contribute to reduce the patient's quality of life. There are no therapies to treat the neurological sequelae of cerebral malaria. Mesenchymal stromal cells (MSCs) may be an alternative, since they have been used as therapy for neurodegenerative diseases and traumatic lesions of the central nervous system. So far, no study has investigated the effects of MSC therapy on the blood-brain barrier, leukocyte rolling and adherence in the brain, and depression likebehavior in experimental cerebral malaria.

Methods: Male C57BL/6 mice were infected with Plasmodium berghei ANKA (PbA, $1 \times 10^{6} \mathrm{PbA}$-parasitized red blood cells, intraperitoneally). At day 6, PbA-infected animals received chloroquine $(25 \mathrm{mg} / \mathrm{kg}$ orally for seven consecutive days) as the antimalarial treatment and were then randomized to receive MSCs $\left(1 \times 10^{5}\right.$ cells in $0.05 \mathrm{ml}$ of saline/ mouse) or saline $(0.05 \mathrm{ml})$ intravenously. Parasitemia, clinical score, and survival rate were analyzed throughout the experiments. Evans blue assay was performed at 6, 7, and 15 days post-infection (dpi). Behavioral tests were performed at 5 and $15 \mathrm{dpi}$. Intravital microscopy experiments and brain-derived neurotrophic factor (BDNF) protein expression analyses were performed at $7 \mathrm{dpi}$, whereas inflammatory mediators were measured at $15 \mathrm{dpi}$. In vitro, endothelial cells were used to evaluate the effects of conditioned media derived from MSCS (CMMSC) on cell viability by lactate dehydrogenase $(\mathrm{LDH})$ release.

(Continued on next page)
\end{abstract}

\footnotetext{
* Correspondence: tati.maron@gmail.com; tatiana.maron@ioc.fiocruz.br

${ }^{1}$ Laboratory of Immunopharmacology, Oswaldo Cruz Institute, Oswaldo Cruz

Foundation, Fiocruz, Av. Brasil, 4365, Pavilhão 108, sala 45, Manguinhos, Rio

de Janeiro, RJ 21040-360, Brazil

${ }^{4}$ National Institute of Science and Technology on Neuroimmunomodulation, Rio de Janeiro, RJ, Brazil

Full list of author information is available at the end of the article
}

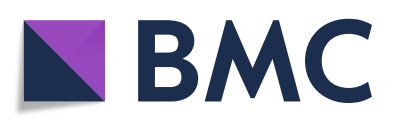

( ) The Author(s). 2020 Open Access This article is licensed under a Creative Commons Attribution 4.0 International License, which permits use, sharing, adaptation, distribution and reproduction in any medium or format, as long as you give appropriate credit to the original author(s) and the source, provide a link to the Creative Commons licence, and indicate if changes were made. The images or other third party material in this article are included in the article's Creative Commons licence, unless indicated otherwise in a credit line to the material. If material is not included in the article's Creative Commons licence and your intended use is not permitted by statutory regulation or exceeds the permitted use, you will need to obtain permission directly from the copyright holder. To view a copy of this licence, visit http://creativecommons.org/licenses/by/4.0/. The Creative Commons Public Domain Dedication waiver (http://creativecommons.org/publicdomain/zero/1.0/) applies to the data made available in this article, unless otherwise stated in a credit line to the data. 
(Continued from previous page)

Results: PbA-infected mice presented increased parasitemia, adherent leukocytes, blood-brain barrier permeability, and reduced BDNF protein levels, as well as depression-like behavior. MSCs mitigated behavioral alterations, restored BDNF and transforming growth factor (TGF)- $\beta$ protein levels, and reduced blood-brain barrier dysfunction and leukocyte adhesion in the brain microvasculature. In a cultured endothelial cell line stimulated with heme, CMMSC reduced LDH release, suggesting a paracrine mechanism of action.

Conclusion: A single dose of MSCs as adjuvant therapy protected against vascular damage and improved depressionlike behavior in mice that survived experimental cerebral malaria.

Keywords: Malaria, Mesenchymal stromal cells, Blood-brain barrier, Depression

\section{Background}

Cerebral malaria is a significant complication of Plasmodium falciparum infection. Malaria is considered a neglected disease and a leading public health challenge [1]. Approximately $25 \%$ of survivors may develop longterm cognitive alterations [2,3] including memory and learning impairment and behavioral changes, such as anxiety and depression [4, 5]. Inflammatory mediators and accumulation of leukocytes are known modulators of blood-brain barrier (BBB) permeability [6], which may lead to cognitive dysfunction in experimental models of infectious diseases, such as malaria [7, 8] and sepsis [9]. Even with successful antimalarial treatment, cerebral malaria survivors can present cognitive and behavioral deficits. These neurological damages can have a critical impact on educational outcomes and socioeconomic status over time, and there is no treatment or effective prophylaxis; thus, new interventions are needed.

In our previous study, we were the first to demonstrate that mesenchymal stromal cell (MSC) administration protected BBB disruption and decreased neuroinflammation after cecal ligation and puncture (CLP) induced sepsis. Additionally, MSC therapy improved spatial and aversive memory and anxiety-like behavior in surviving septic mice [9]. Based on the aforementioned, we hypothesized that MSC therapy is a promising alternative in the prevention and reversal of neurological deficits in infectious diseases. In the present study, MSCs were administered as an adjuvant therapy that could mitigate malaria-induced endothelial dysfunction and behavioral impairments that cause cognitive and behavioral disabilities in survivors. In a cerebral malaria experimental model, we evaluated depression-like behavior, BBB integrity, rolling and adhesion of leukocytes in cerebral microcirculation, and inflammatory mediators.

\section{Methods}

\section{Isolation and expansion of mesenchymal stromal cells}

SCs were isolated from 8-week-old C57BL/6 femur and tibia bone marrows, as previously described [10]. Cells were used in the study between the third and fifth passages. For flow cytometry characterization, MSCs were harvested with Accutase (Stemcell Technology, Vancouver, BC, Canada), stained, and immediately acquired on a FACSCalibur system (BD Biosciences Pharmingen, San Diego, CA). The following monoclonal antibodies were used: anti-mouse CD29-PE (eBioscience, San Diego, CA), CD45 PE (Biolegend, San Diego, CA, USA), CD11b FITC (Biolegend, San Diego, CA), CD14 PE (BD Biosciences Pharmingen, San Diego, CA), rat anti-mouse CD90 purified (eBioscience, San Diego, CA) and anti-rat Alexa Fluor 488 (Invitrogen, Waltham, MA), rat IgG2b k Isotype Control FITC (eBioscience, San Diego, CA), rat IgG1 k Isotype Control PE (eBioscience San Diego, CA), and rat IgG2b k Isotype Control PE (eBioscience, San Diego, CA). Data were analyzed using the FlowJo software, version 10.5.3 (Becton Dickinson and Company, Franklin Lakes, NJ).

\section{Experimental protocol}

C57BL/6 adult male mice were inoculated intraperitoneally (i.p.) with $0.2 \mathrm{~mL}$ suspension of $10^{6}$ Plasmodium berghei ANKA (PbA)-parasitized red blood cells. In the control group, mice were inoculated with $10^{6}$ nonparasitized red blood cells (control group, C). At 6 days post-infection (dpi), PbA-infected mice received chloroquine (CQ, Sigma-Aldrich, St. Louis, MO) $(25 \mathrm{mg} / \mathrm{kg}$ orally in $0.2 \mathrm{~mL}$ saline) for seven consecutive days and were further randomized to receive sterile saline (SAL, $0.05 \mathrm{~mL})$ or MSCs $\left(10^{5}\right.$ cells/mouse in $0.05 \mathrm{~mL}$ saline $)$ into the jugular vein. The progression of the experimental model was evaluated by measuring parasitemia, clinical score, body and spleen weights, and survival up to 15 dpi. Parasitemia was measured by blood smear staining analysis. The clinical score was performed based on observations of parameters in a modified SmithKline Beecham, Harwell, Imperial College, Royal London Hospital, phenotype assessment (SHIRPA) protocol [8], where clinical signs, including piloerection, curved trunk, alterations in gait, seizures, limb paralysis, coma, respiratory rate, skin color alterations, heart rate, lacrimation, palpebral closure, decreased grip strength, limb, abdominal and body tone, and body temperature alterations were observed [11]. Evaluators were blinded to 
group assignment. Mice were given ad libitum access to food and water and monitored twice a day for signs of suffering attributable to the experimental model. If any signs of pain were observed, the animal was euthanatized and removed from the experiment. Our institution has an environmental enrichment program for all experimental animals, including cage enrichment accessories such as a mouse swing and cottage, which helps mitigate anxiety and stress reactivity.

\section{Tail suspension test}

Tail suspension test was performed at 5 and $15 \mathrm{dpi}$. Immobility, the dependent measure of behavioral despair, was used to evaluate depressive-like behavior. Mice were attached to a support using tape placed $1 \mathrm{~cm}$ from the tip of their tales, raised to a height of $15 \mathrm{~cm}$, and recorded for $6 \mathrm{~min}$. Immobility time was analyzed in the final 4 min only [12]. Evaluators were blinded to group assignment.

\section{Forced swim test}

Forced swim test was performed at 5 and 15 dpi. Mice were individually placed in a cylindrical tank $(30 \mathrm{~cm}$ in diameter $\times 40 \mathrm{~cm}$ height) filled to a height of $20 \mathrm{~cm}$ with water $\left(25 \pm 2{ }^{\circ} \mathrm{C}\right)$, so their tails could not touch the bottom of the cylinder. Mice were recorded and each test lasted 6 min. Time of immobility (absence of movement to stay afloat with exception to leg kicks) was analyzed in the final 4 min only [13]. Evaluators were blinded to group assignment.

\section{Cytokine and neurotrophin protein levels in the brain} Interleukin (IL)-1 $\beta$, IL-6, IL-10, and transforming growth factor (TGF) $-\beta$ were measured in total brain homogenates at $15 \mathrm{dpi}$, and brain-derived neurotrophic factor (BDNF) was measured in cortex and hippocampus homogenates at 7 dpi. We used commercially available ELISA kits and followed the manufacturers' instructions (R\&D Systems, Minneapolis, MN, and Abcam, Cambridge, UK).

\section{Evans blue dye assay}

Evans blue dye assay was performed at 6, 7, and $15 \mathrm{dpi}$. Animals were anesthetized by intraperitoneal (i.p.) injection of ketamine $(100 \mathrm{mg} / \mathrm{kg})$ and xylazine $(10 \mathrm{mg} / \mathrm{kg})$ and injected with $2 \%$ Evans blue dye into the retroorbital venous sinus. After $1 \mathrm{~h}$, mice were euthanized with ketamine $(300 \mathrm{mg} / \mathrm{kg})$ and xylazine $(30 \mathrm{mg} / \mathrm{kg})$ i.p. and their brains were removed and placed in formamide. After $24 \mathrm{~h}$ of incubation at $37^{\circ} \mathrm{C}$, Evans blue dye $(\mu \mathrm{g} / \mathrm{mg}$ of brain weight) was quantified by spectrophotometry.

\section{Immunofluorescence microscopy}

Mice were anesthetized ketamine $(300 \mathrm{mg} / \mathrm{kg})$ and xylazine $(30 \mathrm{mg} / \mathrm{kg})$ i.p., and cardiac perfusion was performed with a peristaltic pump. Their brains were dissected and post-fixed in $4 \%$ paraformaldehyde. After embedded in optimal cutting temperature (OCT) compound, frozen longitudinal sections $(12-\mu \mathrm{m}$ thick) through the subventricular zone were prepared. The nuclei were stained with mounting medium containing DAPI (4',6-diamidino-2-phenylindole) (Vector Laboratories). The slides were photographed at $\times 40$ magnification on the Apotome microscope (Zeiss) coupled to a digital camera (AxioCam, Zeiss).

\section{Intravital microscopy through cranial window}

Cerebral microcirculation in mice was assessed as previously described [14]. Briefly, animals were anesthetized with ketamine $(100 \mathrm{mg} / \mathrm{kg})$ and xylazine $(10 \mathrm{mg} / \mathrm{kg})$ i.p. at $7 \mathrm{dpi}$ and placed in a stereotaxic frame. A midline skin incision exposed the left parietal bone and a craniotomy was performed over the temporal parietal bone ( $5 \mathrm{~mm}$ lateral incision between the coronal and the lambdoid sutures) with a hand-held drill to expose the cortical microcirculation. The cranial window was suffused with artificial cerebrospinal fluid (in mmol: $\mathrm{NaCl}$, 132; $\mathrm{KCl}, 2.95 ; \mathrm{CaCl} 2,1.71 ; \mathrm{MgCl} 2,0.64 ; \mathrm{NaHCO} 3,24.6$; dextrose, 3.71; and urea, 6.7; at $37^{\circ} \mathrm{C}, \mathrm{pH}$ 7.4). Animals were placed under an upright fixed-stage intravital microscope equipped with a LED lamp (Zeiss, model SCOPE AXIO, Oberkochen, Germany) coupled to a Zeiss AxioCam with an $\times 20$ water immersion objective producing a final magnification of $\times 200$. Images were captured and processed using ZEN software (Zeiss, Oberkochen, Germany).

The visualization of the brain microvascular surface and the chosen field was facilitated by intravenous administration of $0.1 \mathrm{~mL} 2 \%$ fluorescein isothiocyanate (FITC)-labeled dextran (molecular weight 150,000) and by epiillumination at $460-490 \mathrm{~nm}$ using a $520-\mathrm{nm}$ emission filter. Leukocytes were labeled using rhodamine-6G fluorescent dye $(0.3 \mathrm{mg} / \mathrm{kg})$ and visualized by epi-illumination at 536-556 nm excitation using a $615-\mathrm{nm}$ emission wavelength. Analysis of leukocyte-endothelium interactions was carried out by examining four randomly selected venular segments (30 to $100 \mathrm{~mm}$ in diameter) in each preparation. Rolling leukocytes were defined as the number of cells crossing the venular segment at a speed slower than red blood cells for $1 \mathrm{~min}$. Adherent leukocytes were defined as the total number of leukocytes that were rigidly attached to the endothelium and did not change position during $1 \mathrm{~min}$ of observation and expressed as the number of cells $/ \mathrm{min} / 100 \mu \mathrm{m}$.

\section{In vitro experimental protocol}

Human microvascular endothelial cells (HMEC, ATCC CRL-3243) were routinely cultured in MCDB131 growth medium (Gibco, Waltham, MA), supplemented with 10 
$\mathrm{ng} / \mathrm{mL}$ epidermal growth factor (EGF, Sigma-Aldrich, St. Louis, MO), $1 \mu \mathrm{g} / \mathrm{mL}$ hydrocortisone (Sigma-AldrichSt. Louis, Missouri, E Sigma-Aldrich, St. Louis, MO, USA), $10 \mathrm{mM}$ L-Glutamine (Gibco-Waltham, MA, USA), fetal bovine serum (FBS) to a final concentration of $10 \%$ (Gibco-Waltham, MA, USA), Hepes $20 \mathrm{Mm}$ (Sigma-Aldrich, St. Louis, MO), and penicillin and streptomycin to a final concentration of $2 \%$ (GibcoWaltham, MA, USA). Cells were grown at $37^{\circ} \mathrm{C}$ in humidified atmosphere of $5 \% \mathrm{CO}_{2}$ until reaching $80-90 \%$ confluence before passaging. HMECs were used between passages 26 and 31. For experiments, HMECs were incubated for $24 \mathrm{~h}$ with complete growth medium and treated with lipopolysaccharide (LPS, $1 \mu \mathrm{g} / \mathrm{mL}$; SigmaAldrich, St. Louis, MO) and heme (40 Mm; Frontier Science, Boston, MA). After $24 \mathrm{~h}$, cells were incubated with MSC-conditioned media (CM), prepared as described elsewhere [9]. Lactate dehydrogenase (LDH) release was measured at 6, 18, and $24 \mathrm{~h}$ with the commercially available CytoTox 96 Non-Radioactive Cytotoxicity Assay (Promega, Madison, WI).

\section{Statistical analysis}

We used a one-way analysis of variance with post-hoc Tukey test to assess the differences between more than two groups and Student's $t$ test when data from only two groups were analyzed. Survival curves were derived by the Kaplan-Meier method and compared by the log-rank test. We expressed the data as mean \pm SEM and set the significance level to 5\%. We performed all tests in GraphPad Prism 6.0 (GraphPad Software, San Diego, CA).

\section{Results}

Mesenchymal stromal cell phenotypic characterization

In accordance with the International Society for Cellular Therapy [15], we observed that isolated mesenchymal stromal cells (MSCs) were adherent to cell culture flasks, capable of differentiating into adipocytes (Supplementary Fig. 1a), positive for the mesenchymal markers CD90 and CD29, and negative for the hematopoietic markers CD45, CD11b, and CD14 (Supplementary Fig. 1b).

\section{Mesenchymal stromal cell effects on the experimental cerebral malaria model}

Parasitemia in mice peaked at 6 days post-infection (dpi), coinciding with the start of chloroquine (CQ) treatment. In both $\mathrm{PbA}+\mathrm{CQ}+\mathrm{SAL}$ and $\mathrm{PbA}+\mathrm{CQ}+\mathrm{MSC}$ experimental groups, parasitemia began to decrease from 7 to $15 \mathrm{dpi}$. MSC therapy neither interfered with the progression of $\mathrm{PbA}$ infection nor recovery of animals following chloroquine administration (Fig. 1a). PbA-infected mice presented higher clinical score at 6, 7, and 9 dpi when

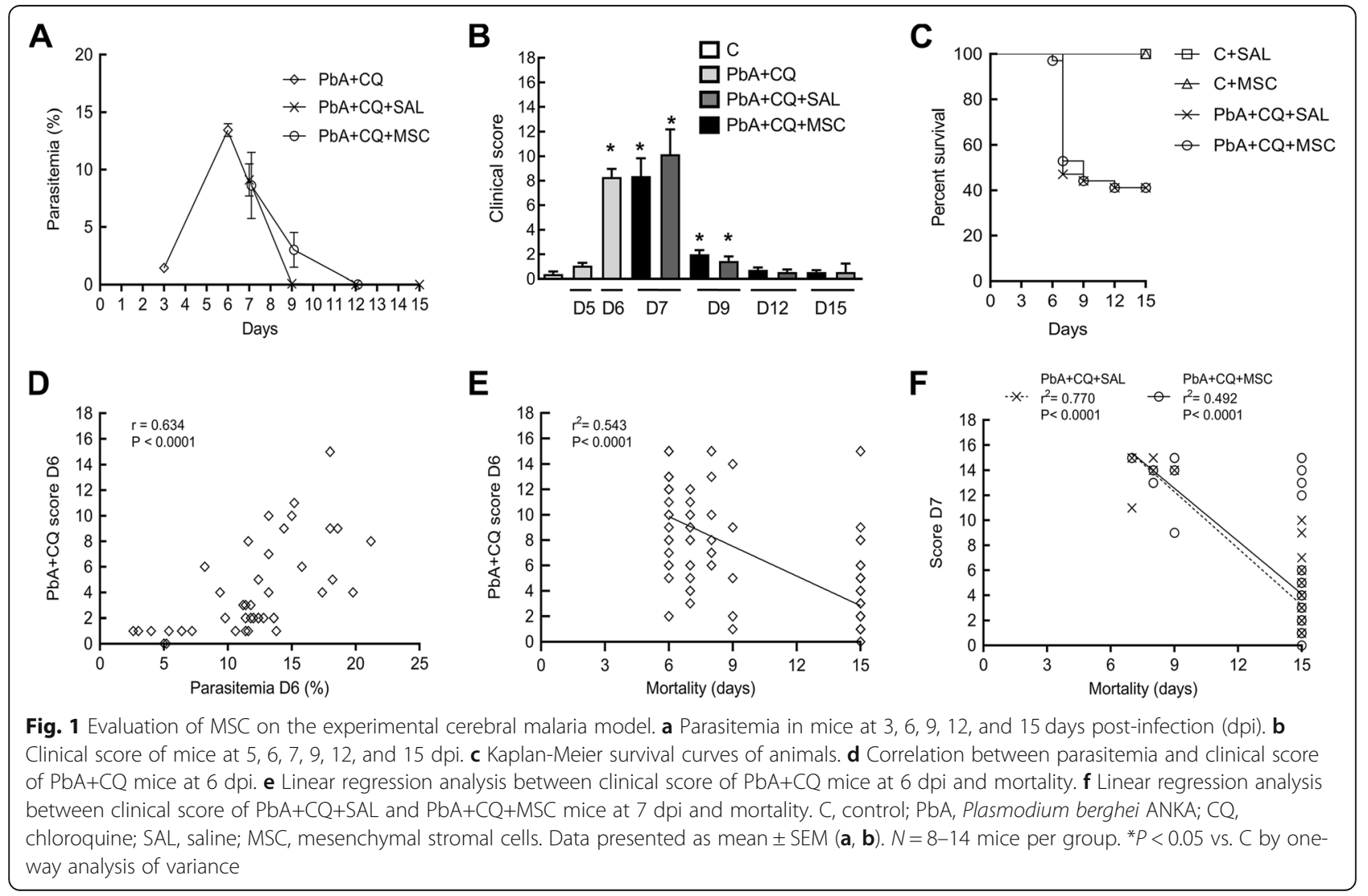


compared to the non-infected control group (Fig. 1b). MSC-treated mice $(\mathrm{PbA}+\mathrm{CQ}+\mathrm{MSC})$ had a similar clinical score (Fig. 1b) and similar survival rates (Fig. 1c) when compared to the non-treated group ( $\mathrm{PbA}+\mathrm{CQ}+\mathrm{SAL})$. Correlation analysis was performed between parasitemia and clinical score at $6 \mathrm{dpi}$ in the $\mathrm{PbA}+\mathrm{CQ}$ group, and a positive association was observed between these two variables (Fig. 1d). Regression analysis was also performed between clinical score at 6 dpi and mortality (Fig. 1e) as well as between the clinical score at $7 \mathrm{dpi}$ and mortality in the $\mathrm{PbA}+\mathrm{CQ}+\mathrm{MSC}$ group (Fig. 1f). Although MSC treatment did not alter survival rates in mice, regression analysis showed that mice from the $\mathrm{PbA}+\mathrm{CQ}+\mathrm{MSC}$ group with a high clinical score at $7 \mathrm{dpi}$ survived until $15 \mathrm{dpi}$, which was not observed in mice from the $\mathrm{PbA}+\mathrm{CQ}+\mathrm{SAL}$ group (Fig. 1f). The $\mathrm{PbA}+\mathrm{CQ}+\mathrm{SAL}$ and $\mathrm{PbA}+\mathrm{CQ}+\mathrm{MSC}$ groups presented increased spleen weight at 7 and 15 dpi (Supplementary Fig. 2).
Mesenchymal stromal cells preserved blood-brain barrier integrity and reduced adherent leukocytes

PbA-infected mice exhibited loss of blood-brain barrier (BBB) integrity compared to the control group at 6 (Fig. 2a) and 7 dpi (Fig. 2b), but not at 15 dpi (Fig. 2c). The PbA+ $\mathrm{CQ}+\mathrm{MSC}$ group showed higher $\mathrm{BBB}$ integrity in comparison to the $\mathrm{PbA}+\mathrm{CQ}+\mathrm{SAL}$ group at $7 \mathrm{dpi}$ (Fig. $2 \mathrm{~b}$ ). There was no significant difference between the $\mathrm{C}+\mathrm{SAL}$ and $\mathrm{C}+\mathrm{MSC}$ groups (Supplementary Table 1). The presence of erythrocytes in the brain parenchyma was observed only in the $\mathrm{PbA}+\mathrm{CQ}+\mathrm{SAL}$ group (Fig. 2d). To further clarify this point, we evaluated inflammatory cell dynamics and the leukocyteendothelium interaction in cerebral microcirculation using intravital microscopy by epi-illumination and fluorescence. We observed an expressive number of rolling (Fig. 3a, b) and adhered (Fig. 3a, c) leukocytes in the cerebral post-capillary venules of different calibers, causing stagnation of the blood cells and stasis of the flow in the mice from the $\mathrm{PbA}+\mathrm{CQ}+$

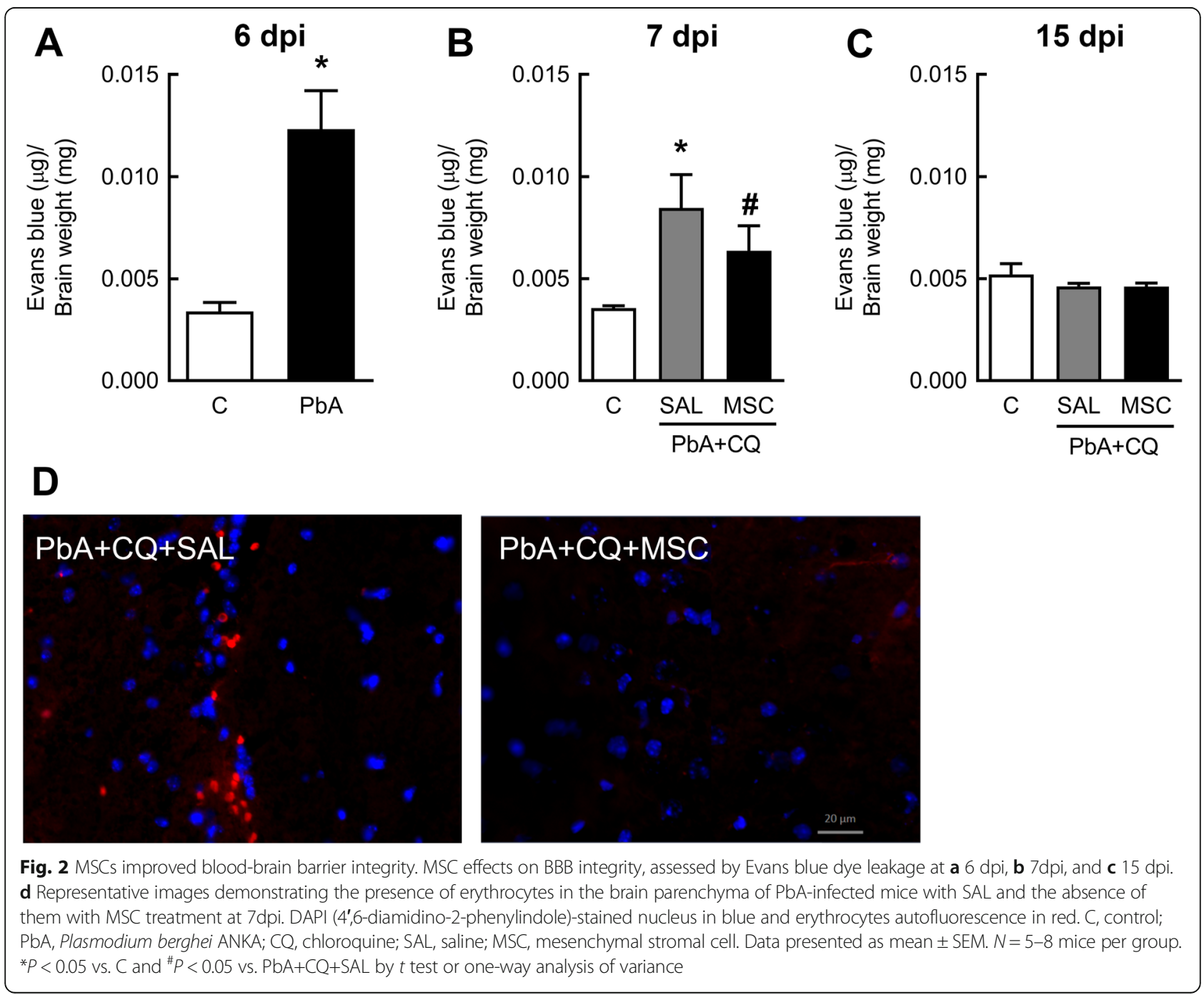




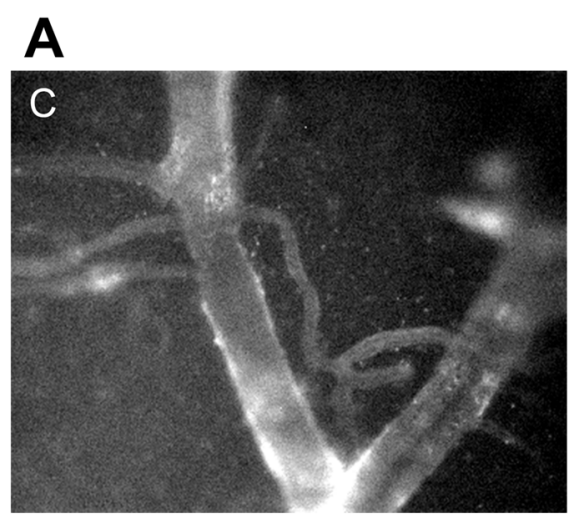

B
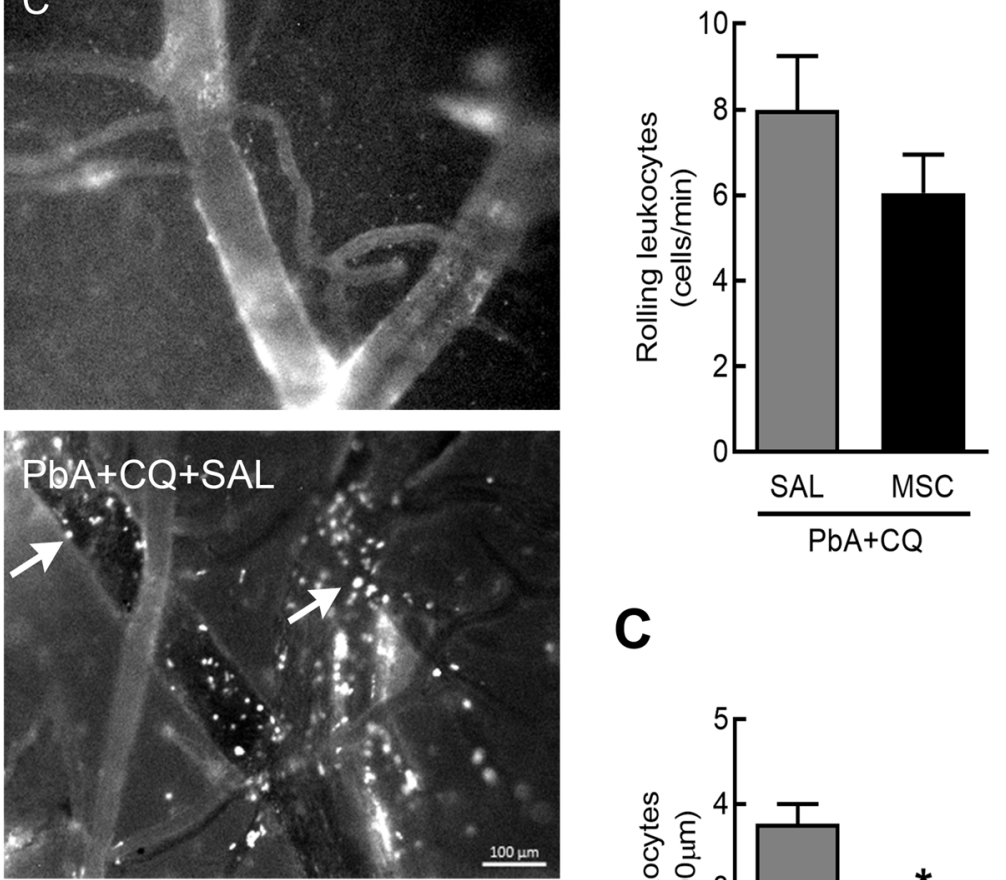

C
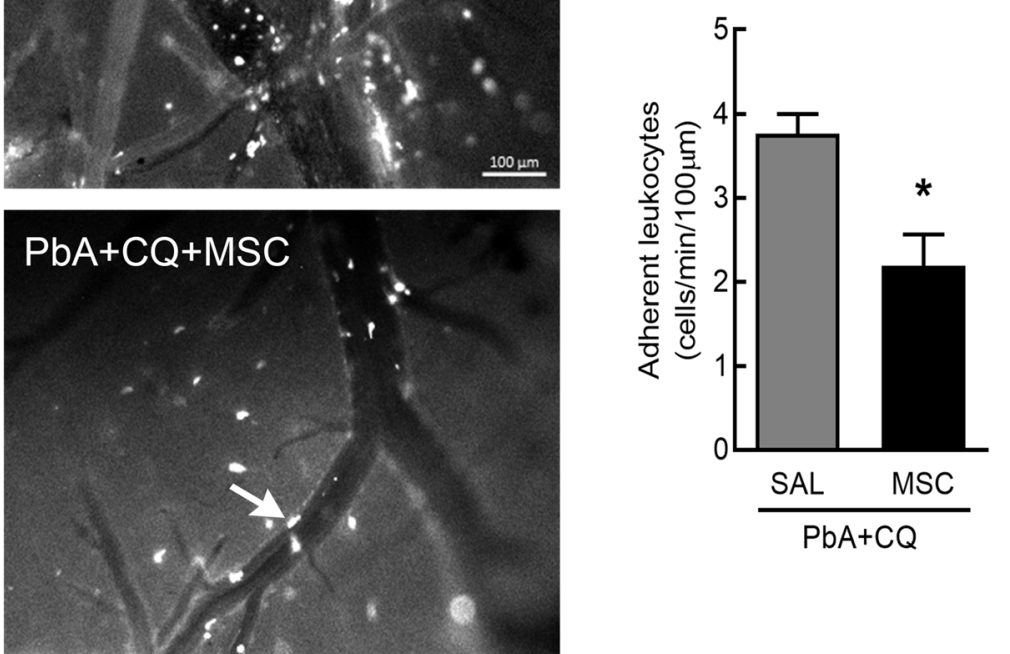

Fig. 3 Evaluation of MSCs on rolling and adherent leukocytes in brain microcirculation at 7 dpi. a Representative images of leukocyte-endothelium interaction in the brain microcirculation of control and PbA-infected mice with or without treatment with MSC or SAL. $\mathbf{b}$ Rolling and $\mathbf{c}$ adherent rhodamine 6G-labeled leukocytes evaluated by intravital fluorescence microscopy on cerebral post-capillary venules. C, control; PbA, Plasmodium berghei ANKA; CQ, chloroquine; SAL, saline; MSC, mesenchymal stromal cell. Data presented as mean \pm SEM. $N=4$ mice per group. ${ }^{*} P<0.05$ vs. $\mathrm{PbA}+\mathrm{CQ}+\mathrm{SAL}$ by $t$ test. ${ }^{*} P<0.05$. Scale bar is $100 \mu \mathrm{m}$

SAL group (Supplementary video 1) compared to control group (Fig. 3a, Supplementary video 2). MSC treatment alleviated inflammation in cerebral microcirculation, evidenced by a reduction of adhered leukocytes (Fig. 3a, c, Supplementary video 3). Accordingly, conditioned media derived from MSC (CMMSC) reduced lactate dehydrogenase (LDH) release in cultured HMECs stimulated with heme at 6,18 , and $24 \mathrm{~h}$ (Fig. 4).

\section{Mesenchymal stromal cells improved depression-like} behavior

PbA-infected mice showed more immobility in the tail suspension (Fig. 5a) and forced swimming (Fig. 5b) tests at 5 dpi compared to control mice. At $15 \mathrm{dpi}$, MSC therapy reversed depression-like behavior in both tests (Fig. 5c, d) compared to mice from the $\mathrm{PbA}+\mathrm{CQ}+\mathrm{SAL}$ group. There was no significant difference between C+SAL and C+MSC groups (Supplementary Table 1).

\section{Mesenchymal stromal cell effects on BDNF and Neuroinflammation}

MSC therapy restored BDNF levels in the cortex at $7 \mathrm{dpi}$ compared to mice from the $\mathrm{PbA}+\mathrm{CQ}+\mathrm{SAL}$ group (Fig. 6a). There was no significant difference between C+SAL and C+MSC groups (Supplementary Table 1). At $15 \mathrm{dpi}$, mice from the $\mathrm{PbA}+\mathrm{CQ}+\mathrm{SAL}$ group showed 


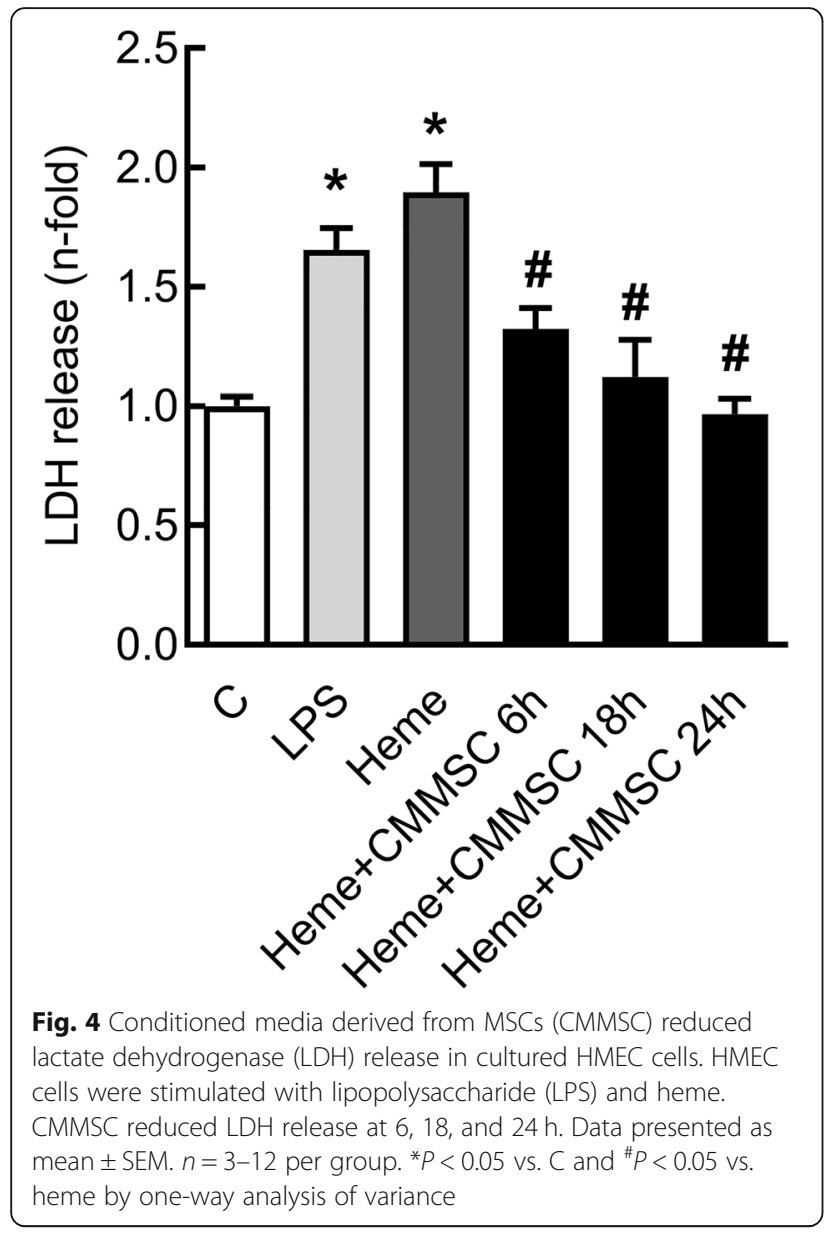

no differences in IL-1 $\beta$, IL-6, and IL-10 secretion levels (Fig. $7 \mathrm{a}-\mathrm{c}$ ) when compared to control mice, while TGF$\beta$ levels were increased in this group (Fig. $7 d$ ).

\section{Discussion}

In this study, we show that mesenchymal stromal cells, as an adjuvant therapy for brain damage, reduced leukocyte-endothelium interactions in the brain microvasculature, mitigated $\mathrm{BBB}$ damage, and restored $\mathrm{BDNF}$ levels in the cortex of PbA-infected C57BL/6 mice. Furthermore, MSC administration improved depressive-like behavior 15 days after infection in mice that survived cerebral malaria. To the best of our knowledge, this was the first study to demonstrate the positive effects of MSCs as an adjuvant therapy for brain damage in an experimental model of malaria.

We chose to initiate chloroquine administration 6 days after $\mathrm{PbA}$ infection as the antimalarial therapy. The strong correlation between parasitemia and clinical score 6 days post-infection enabled the evaluation of the severity and progression of the disease. This analysis allowed us to use the clinical score as a cutoff point for infection, making the study more reliable and less susceptible to

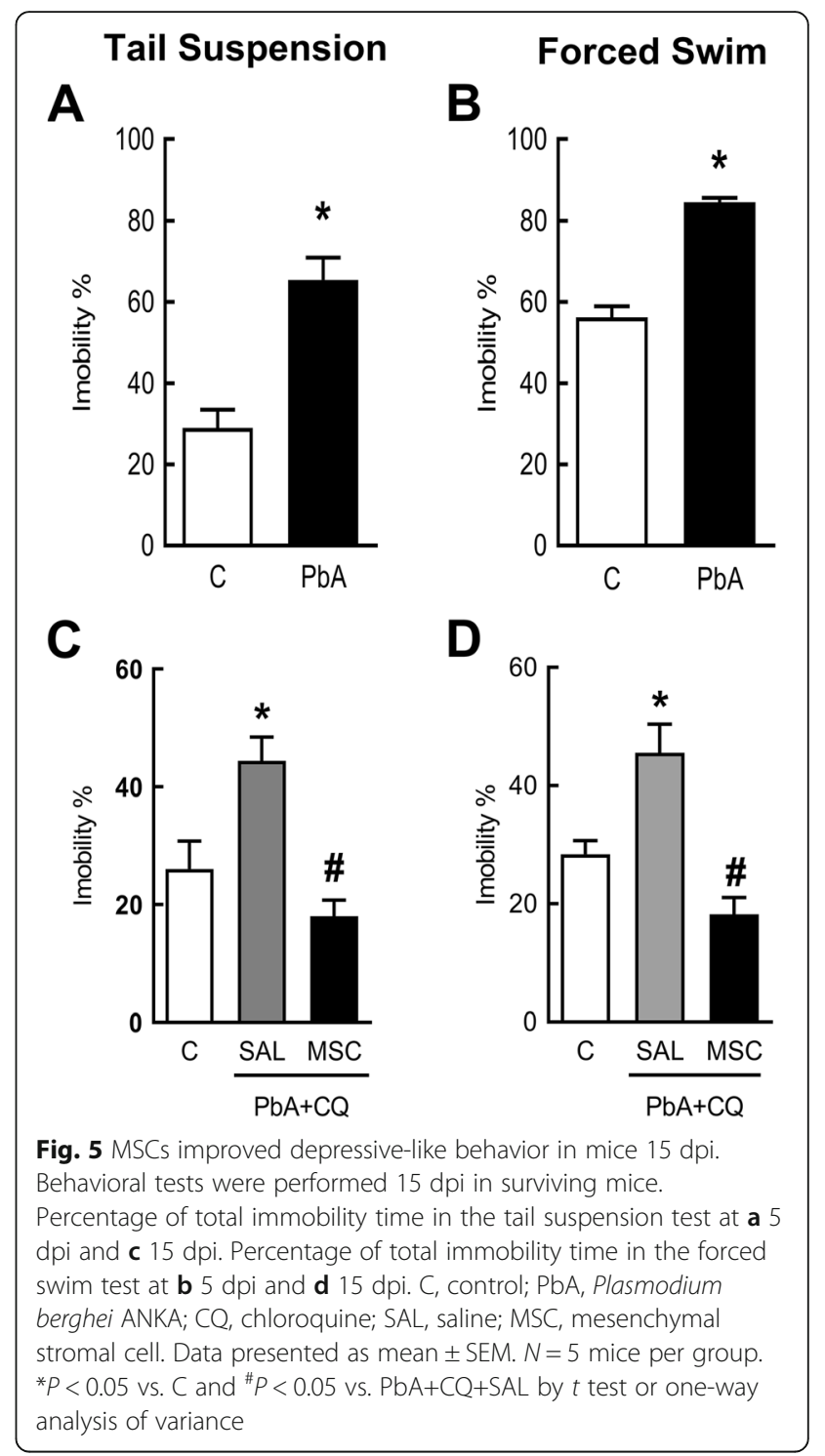

outliers. We excluded data from mice that presented a clinical score below 4, considered as abnormal progression of the infection. Also, using clinical score and survival linear regression analysis, we identified that mice with higher scores are more likely to die before day 15 .

The MSC treatment did not modulate parasitemia, clinical score, or survival rates in the infected mice. Although MSC therapy did not improved survival rates, we noticed that mice in the $\mathrm{PbA}+\mathrm{CQ}+\mathrm{MSC}$ group with high scores at day 7 post-infection managed to reach day 15 , which did not occur in the $\mathrm{PbA}+\mathrm{CQ}+\mathrm{SAL}$ group. Our results differ from Souza and colleagues, who show that MSCs decreased parasitemia and improved survival, which could be explained by their use of a different protocol. They administered MSCs only $24 \mathrm{~h}$ after PbA infection and performed analysis 4 days after $\mathrm{PbA}$ infection [16], while, in the present study, we administered 


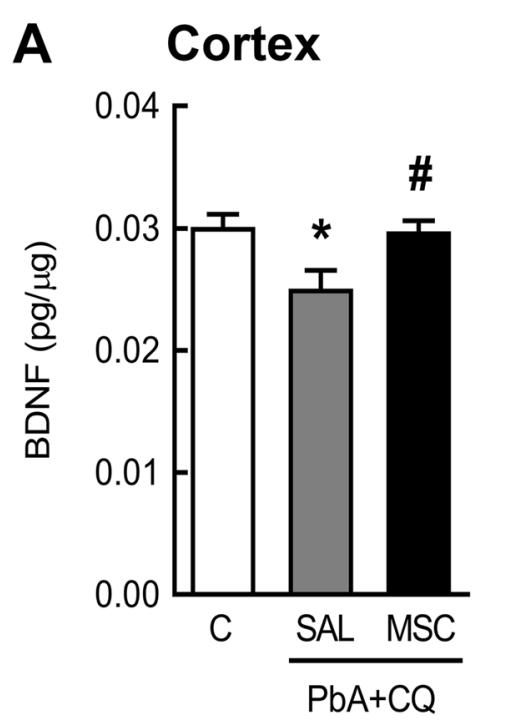

B Hippocampus

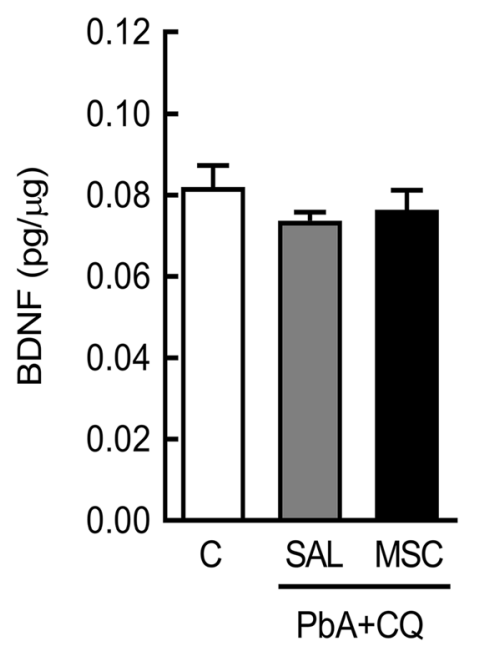

Fig. 6 Effects of MSCs on BDNF at 7 dpi. BDNF protein levels in the a cortex and $\mathbf{b}$ hippocampus. C, control; PbA, Plasmodium berghei ANKA; $C Q$, chloroquine; SAL, saline; MSC, mesenchymal stromal cell. Data presented as mean \pm SEM. $N=4-11$ mice per group, ${ }^{*} P<0.05$ vs. $C$ and ${ }^{\#} P<0.05$ vs. $\mathrm{PbA}+\mathrm{CQ}+\mathrm{SAL}$ by one-way analysis of variance

MSCs on the sixth day post-infection, when mice presented both high parasitemia and clinical score, and analysis was performed at 7 and 15 days after infection. Similarly, in a previous study from our group, MSCs administered $6 \mathrm{~h}$ after sepsis induction did not improve clinical score and survival rates [9]. However, when MSCs was administered before sepsis induction, we observed improvement in these parameters (unpublished data), reinforcing that timing is relevant for MSC therapy.

The pathogenesis of cerebral malaria comprises cytoadherence and sequestration of infected red blood cells in the cerebral microvasculature and an inflammatory response to the parasite in the central nervous system. The increase of inflammatory signals elicits vascular leakage and might contribute to microcirculatory dysfunction and neurological symptoms [17]. The activation of multiple cell death pathways in endothelial cells directly mediated by activated $\mathrm{T}$ lymphocytes disrupts blood-brain barrier integrity [18]. The T lymphocyte response persists after the resolution of the infection following antimalarial treatment and might be involved in later outcomes in experimental cerebral malaria [19]. We observed BBB disruption at days 6 and 7 post-infection and a higher level of LDH release when HMEC cells were stimulated with heme, indicating increased cell death due to heme from the presence of $\mathrm{PbA}$-infected red cells in the brain. Heme is produced by malaria trophozoites during intra-erythrocytic development and has an important role in the pathophysiology of cerebral malaria [20,21]. Increased levels of free heme contribute to inflammation, tissue damage, and
BBB dysfunction [22, 23] and lead to apoptosis of brain endothelial cells in vitro [20]. Increased number of leukocytes and platelets at the site of parasite sequestration in the brain and upregulation of chemokines and cytokines are present in malaria patients $[24,25]$ and in murine models of cerebral malaria $[26,27]$. Accordingly, we observed an increase in adherent leukocytes in the brain microvasculature in $\mathrm{PbA}+\mathrm{CQ}+\mathrm{SAL}$ mice. Mesenchymal stromal cell therapy has beneficial effects in infectious diseases. In a previous study, mesenchymal stromal cell therapy had beneficial effects in infectious diseases. We observed that MSC administration prevented $\mathrm{BBB}$ damage and cognitive and behavioral alterations, as well as reduced astrogliosis in an experimental model of CLP-induced sepsis [9]. Herein, we were the first to demonstrate that intravenous infusion of a single dose of MSC mitigated BBB dysfunction and reduced leukocyte adhesion to brain microvasculature in $\mathrm{PbA}$ infected mice. In addition, conditioned media derived from MSCs increased cell viability in HMEC cultured cells stimulated with heme. According to the literature, MSCs are primarily entrapped in the lungs after intravenous delivery; however, the amount of bone marrow cells trapped within the pulmonary and brain vasculature after systemic administration is small [28-32], suggesting that cellular migration and engraftment are not required for positive effects to occur; instead, MSCs appear to act predominantly through a paracrine mechanism [33].

In this work, treatment with MSCs significantly reduced leukocyte adhesion in post-capillary venules, even though the decrease in rolling was not shown to be 

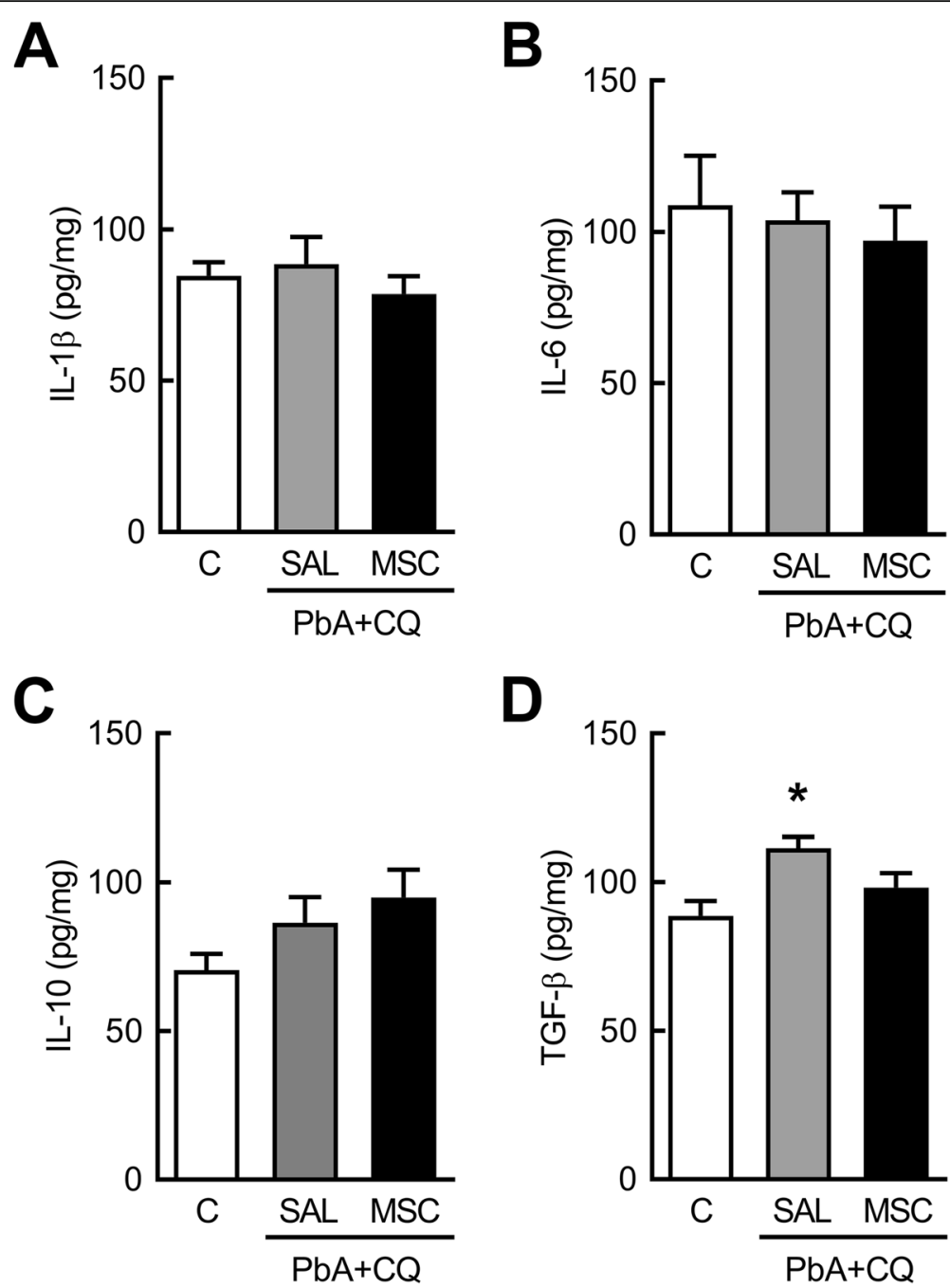

D

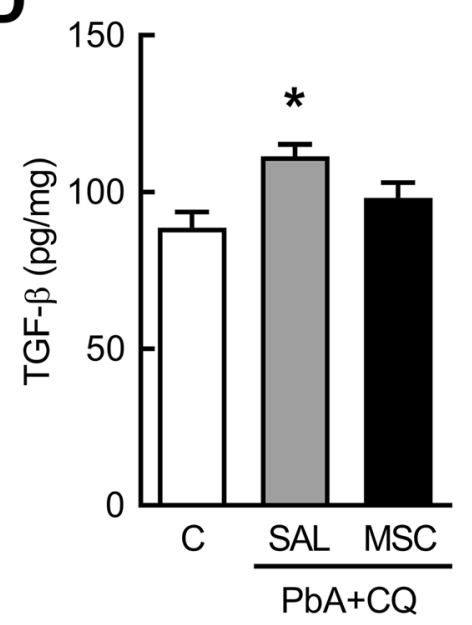

Fig. 7 Effects of MSCS on neuroinflammation 15 dpi. a interleukin (IL)-1 $\beta, \mathbf{b}\|\mathrm{L}-6, \mathbf{c}\| \mathrm{L}-10$, and $\mathbf{d}$ transforming growth factor (TGF)- $\beta$ brain protein levels. C, control; PbA, Plasmodium berghei ANKA; CQ, chloroquine; SAL, saline; MSC, mesenchymal stromal cell. Data presented as mean \pm SEM. $N=5-9$ mice per group, ${ }^{*} P<0.05$ vs. $C$ by one-way analysis of variance

statistically significant. One explanation may be the possible action of the MSC on adhesion molecules, such as intercellular adhesion molecule (ICAM)-1, but not on selectins. The former are key elements for rigid leukocyte adhesion to the vascular endothelium. On the other hand, selectins promote weak binding of leukocytes to the endothelium, a feature of the rolling process. Corroborating our finding, a recent study demonstrated that human placenta MSCs can exert an anti-inflammatory effect. Authors showed significantly attenuated expression of NF- $\mathrm{KB}$ messenger RNA, inhibiting overactivation of NF- $\mathrm{KB}$ and further reducing the generation of tumor necrosis factor (TNF) $\alpha$ and ICAM- 1 by MSCs in an inflammatory mouse model of kidney injury [34].

Behavioral disorders are likely to become neglected in patients with more severe neurological damage, such as cognitive impairments and motor function deficits, frequently observed in cerebral malaria survivors $[2,35]$. Individuals infected with Plasmodium falciparum present a significant increase in anxiety and depression [4, 36]. Several studies in experimental models of malaria also demonstrated anxiety and depression-like behavior alterations [37-39]. We also observed an increase in depression like-behavior in PbA-infected mice, while MSC treatment mitigated this behavioral alteration. We performed tail suspension and forced swim tests on days 5 and 15 after PbA infection. Both tests are commonly used in the study of potential antidepressant drugs. They assume that if an animal cannot escape or hold onto nearby surfaces, it will first make efforts to escape but ultimately will exhibit immobility that may be considered a measure of behavioral despair $[12,13]$. The underlying MSC mechanism of action may involve BDNF protein levels in the cortex. Some cortical brain areas are implicated in 
depression [40] and decreased expression of neurotrophins and impaired neurogenesis were detected in animal models of depression [41, 42]. BDNF modulates survival of neurons and plasticity mechanisms in learning and memory [43] and plays an important role in the pathogenesis of depression [41, 44, 45]. The activation of the immune system during disease or stress conditions may inhibit neurotrophin release and contribute to the deleterious effects in adult neurogenesis and cognitive function [46, 47]. Reduced BDNF expression levels are associated with cognitive and behavioral disorders in neurological disorders, such as cerebral malaria [48-50]. Previous studies have showed reduced BDNF mRNA expression in the frontal cortex and the hippocampus [37] and in various brain regions, including the thalamus, hypothalamus, cerebellum, and brainstem in PbA-infected mice [51]. The downregulation of BDNF may be a point of no return for the neurological damages observed in cerebral malaria. In the present study, MSC treatment restored BDNF levels, in accordance with others that demonstrated that MSC therapy increases BDNF levels in the brain and elicits functional improvement $[52,53]$. Although MSCs secretes BDNF, this might not be the only mechanism of action. MSC protective effects on the BBB may lead to a reduction in the activation of microglia and astrocytes that can modulate neuroinflammation and the development of the neurological damage $[8,9]$. BBB dysfunction has been correlated to the influx of proinflammatory mediators into the brain tissue and consequent depression-like behavior [54-57].

Since the malaria parasite is not neurotropic, the neurological sequelae may be due to a neuroinflammatory effects generated in response to infection $[17,19]$. The imbalance of pro- and anti-inflammatory cytokines in the brain is related to the pathogenesis of cerebral malaria. Most studies evaluate cytokines and chemokines in the acute phase of the disease [5, 58], whereas, we chose to analyze inflammatory mediators at day 15 , when depression-like behavior was still observed in mice. We then observed that IL-1 $\beta$, IL- 6 , and IL-10 protein expression levels were already restored in $\mathrm{PbA}$ infected mice brains and that TGF- $\beta$ protein expression levels were increased in the PbA+CQ+SAL group. TGF$\beta$ modulates the inflammatory response in the central nervous system as well as the proliferation of microglia and astrocytes $[59,60]$. In addition, TGF- $\beta$ upregulation may be detrimental to regeneration. Members of the TGF- $\beta$ family inhibit neurogenesis by blocking proliferation of precursor cells in the adult brain [61], and TGF$\beta$ intracerebroventricular injection reduced the number of proliferating cells in the hippocampus and subventricular zone in adult mice [62].

\section{Conclusion}

In mice that survived experimental cerebral malaria, a single dose of MSCs conferred a protective effect on the blood-brain barrier, reduced the number of adherent leukocytes, and restored BDNF protein levels within $24 \mathrm{~h}$ of administration. In addition, MSC therapy improved depressive-like behavior 15 days after PbA infection. Thus, we believe that MSC administration as an adjuvant therapy for infectious diseases, such as malaria, may be a promising treatment, especially for neurological damages.

\section{Supplementary information}

Supplementary information accompanies this paper at https://doi.org/10. 1186/s13287-020-01874-6.

\begin{abstract}
Additional file 1: Supplementary Fig. 1. MSC phenotypic
characterization. a Adipogenic (Oil red $\mathrm{O}$ staining) differentiation of mesenchymal stromal cells (MSCs) isolated from 8-week-old C57BL/6 mice femur and tibia bone marrow. b Representative FSC vs. SSC dot plot showing the gate for MSCs derived from C57BL/6 mice, between the third and fifth passages. Histograms in red or green showing expression of mesenchymal markers CD29 and CD90; isotype control or only anti-rat Alexa Fluor 488 antibody in gray. MSCs were negative for expression of the hematopoietic markers CD45, CD11b, and CD14.
\end{abstract}

Additional file 2: Supplementary Fig. 2. Evaluation of spleen weight in mice. Analysis of spleen and body weight at 7 and $15 \mathrm{dpi}$. Abbreviations: C, control; PbA, Plasmodium berghei ANKA; CQ, chloroquine; SAL, saline; MSC, mesenchymal stromal cells. Data presented as mean \pm SEM. $N=8-15$ mice per group, ${ }^{*} P<0.05$ vs. $C$ by one-way analysis of variance.

Additional file 3: Supplementary Table 1. C+SAL vs. C+MSC groups. Additional file 4: Supplementary video 1.

Additional file 5: Supplementary video 2.

Additional file 6: Supplementary video 3.

\section{Abbreviations}

BBB: Blood-brain barrier; BDNF: Brain-derived neurotrophic factor; C: Control; CMMSC: Conditioned media derived from mesenchymal stromal cells; CQ: Chloroquine; dpi: Days post-infection; IL: Interleukin; LDH: Lactate dehydrogenase; LPS: Lipopolysaccharide; MSC: Mesenchymal stromal cells; $\mathrm{PbA}$ : Plasmodium berghei ANKA; SAL: Saline

\section{Acknowledgements}

We thank Leonardo José de Moura Carvalho for providing Plasmodium berghei ANKA blood samples, Edson Fernandes Assis, Carla Moreira Furtado, Caio Oliveira, and Cecilia Hedin-Pereira for critical discussions and their technical skills.

\section{Authors' contributions}

MNL performed all animal experiments, collected data, analyzed data, and drafted the article. HAD performed animal experiments, collected data from behavioral tasks, and measured inflammatory mediators. VE performed intravital microscopy experiments and data analysis. AYOS performed and collected data from behavioral animal experiments. KSO and ALV performed flow cytometry experiments and data analysis. BARP performed mesenchymal stromal cell differentiation experiments. RJRXF designed and performed in vitro experiments. PMF and BARP maintained MSCs and performed blood brain barrier integrity animal experiments. VE, CNB, ALV, PRMR, and HCC-F-N made considerable contributions to the study and corrected the article. TM-G designed the study, made substantial contributions to the concept and design of the study, performed statistical analysis, supervised the conduction of the study, and wrote the article. All authors read and approved the final manuscript. 


\section{Funding}

Dr. Maron-Gutierrez was supported by Brazilian Council for Scientific and Technological Development, Inova Fiocruz/Oswaldo Cruz Foundation.

\section{Availability of data and materials}

All data generated or analyzed during this study are included in this published article and its supplementary information files.

\section{Ethics approval and consent to participate}

All animal experiments were approved by the ethics committee of the Oswaldo Cruz Institute (Fiocruz, CEUA-IOC license number L-012/2015). All animals received humane care in compliance with the "Principles of Laboratory Animal Care" formulated by the National Society for Medical Research and the "Guide for the Care and Use of Laboratory Animals" prepared by the National Academy of Sciences, USA.

\section{Consent for publication}

Not applicable

\section{Competing interests}

The authors declare that they have no competing interests.

\section{Author details}

1 Laboratory of Immunopharmacology, Oswaldo Cruz Institute, Oswaldo Cruz Foundation, Fiocruz, Av. Brasil, 4365, Pavilhão 108, sala 45, Manguinhos, Rio de Janeiro, RJ 21040-360, Brazil. '2Laboratory of Pulmonary Investigation, Carlos Chagas Filho Institute of Biophysics, Federal University of Rio de Janeiro, Rio de Janeiro, Brazil. ${ }^{3}$ National Institute of Science and Technology for Regenerative Medicine, Rio de Janeiro, RJ, Brazil. ${ }^{4}$ National Institute of Science and Technology on Neuroimmunomodulation, Rio de Janeiro, RJ, Brazil.

Received: 6 June 2020 Revised: 16 July 2020

Accepted: 4 August 2020 Published online: 26 August 2020

\section{References}

1. Kappe SHI, Vaughan AM, Boddey JA, Cowman AF. That was then but this is now: malaria research in the time of an eradication agenda. Science (80- ). 2010:328:862-6.

2. Idro R, Marsh K, John CC, Newton CRJ. Cerebral malaria: mechanisms of brain injury and strategies for improved neurocognitive outcome. Pediatr Res. 2010;68:267-74.

3. Bruneel F. Human cerebral malaria: 2019 mini review. Rev Neurol (Paris). Elsevier Masson SAS; 2019;6-11. Available from: https://linkinghub.elsevier. com/retrieve/pii/S0035378719306605.

4. Dugbartey AT, Dugbartey MT, Apedo MY. Delayed neuropsychiatric effects of malaria in Ghana. J Nerv Ment Dis. 1998;186:183-6.

5. De Miranda AS, Lacerda-Queiroz N, de Carvalho VM, Rodrigues DH, Rachid MA, Quevedo J, et al. Anxiety-like behavior and proinflammatory cytokine levels in the brain of C57BL/6 mice infected with Plasmodium berghei (strain ANKA). Neurosci Lett. 2011;491:202-6.

6. Abbott NJ. Inflammatory mediators and modulation of blood-brain barrier permeability. Cell Mol Neurobiol. 2000;20:131-47.

7. Azevedo-Quintanilha IG, Vieira-de-Abreu A, Ferreira AC, Reis PA, Silva TI, Nascimento DD, et al. Integrin $a D \beta 2$ influences cerebral edema, leukocyte accumulation and neurologic outcomes in experimental severe malaria. PLoS One. 2019;14:e224610.

8. Reis PA, Estato V, da Silva TI, D'Avila JC, Siqueira LD, Assis EF, et al. Statins decrease neuroinflammation and prevent cognitive impairment after cerebral malaria. PLoS Pathog. 2012;8:e1003099.

9. Silva AYO, Amorim ÉA, Barbosa-Silva MC, Lima MN, Oliveira HA, Granja MG, et al. Mesenchymal stromal cells protect the blood-brain barrier, reduce astrogliosis, and prevent cognitive and behavioral alterations in surviving septic mice. Crit Care Med. 2020;48:e290-8.

10. Maron-Gutierrez T, Silva JD, Asensi KD, Bakker-Abreu I, Shan Y, Diaz BLBL, et al. Effects of mesenchymal stem cell therapy on the time course of pulmonary remodeling depend on the etiology of lung injury in mice. Crit Care Med. 2013;41:319-33.

11. Reis PA, Alexandre PCB, D'Avila JC, Siqueira LD, Antunes B, Estato V, et al. Statins prevent cognitive impairment after sepsis by reverting neuroinflammation, and microcirculatory/endothelial dysfunction. Brain
Behav Immun. 2017;60:293-303 Available from: https://doi.org/10.1016/j.bbi. 2016.11.006.

12. Can A, Dao DT, Terrillion CE, Piantadosi SC, Bhat S, Gould TD. The tail suspension test. J Vis Exp. 2011;59:e3769.

13. Yankelevitch-Yahav R, Franko M, Huly A, Doron R. The forced swim test as a model of depressive-like behavior. J Vis Exp. 2015;97:e52587.

14. Araújo CV, Estato V, Tibiriçá E, Bozza PT, Castro-Faria-Neto HC, Silva AR. PPAR gamma activation protects the brain against microvascular dysfunction in sepsis. Microvasc Res. 2012;84:218-21 Available from: https://doi.org/10. 1016/j.mvr.2012.05.006

15. Dominici M, Le Blanc K, Mueller I, Slaper-Cortenbach I, Marini FC, Krause DS, et al. Minimal criteria for defining multipotent mesenchymal stromal cells. The International Society for Cellular Therapy position statement. Cytotherapy; 2006;8:315-317.

16. Souza MC, Silva JD, Pádua TA, Torres ND, Antunes MA, Xisto DG, et al. Mesenchymal stromal cell therapy attenuated lung and kidney injury but not brain damage in experimental cerebral malaria. Stem Cell Res Ther. 2015;6:1-15.

17. van der Heyde HC, Nolan J, Combes V, Gramaglia I, Grau GE. A unified hypothesis for the genesis of cerebral malaria: sequestration, inflammation and hemostasis leading to microcirculatory dysfunction. Trends Parasitol. 2006;22:503-8.

18. Tan KH, Purcell WM, Heales SJR, McLeod JD, Hurst RD. Activated T cells mediate direct blood-brain barrier endothelial cell death and dysfunction. Neuroreport. 2002;13:2587-91.

19. Vieira LB, Vieira ÉLM, Abreu LKS, Ribeiro FM, Teixeira AL, Rachid MA, et al. Tlymphocytes response persists following Plasmodium berghei strain Anka infection resolution and may contribute to later experimental cerebral malaria outcomes. J Neuroimmunol. 2019;330:5-11 Available from: https:// doi.org/10.1016/j.jneuroim.2019.02.002.

20. Liu M, Dickinson-Copeland C, Hassana S, Stiles JK. Plasmodium-infected erythrocytes (pRBC) induce endothelial cell apoptosis via a heme-mediated signaling pathway. Drug Des Devel Ther. 2016;10:1009-18.

21. Immenschuh S, Vijayan V, Janciauskiene S, Gueler F. Heme as a target for therapeutic interventions. Front Pharmacol. 2017;8:1-15.

22. Pamplona A, Ferreira A, Balla J, Jeney V, Balla G, Epiphanio S, et al. Heme oxygenase- 1 and carbon monoxide suppress the pathogenesis of experimental cerebral malaria. Nat Med. 2007;13:703-10.

23. Liu M, Amodu AS, Pitts S, Patrickson J, Hibbert JM, Battle M, et al. Heme mediated STAT3 activation in severe malaria. PLoS One. 2012;7:e34280.

24. Hunt NH, Grau GE. Cytokines: accelerators and brakes in the pathogenesis of cerebral malaria. Trends Immunol. 2003;24:491-9.

25. Taylor TE, Fu WJ, Carr RA, Whitten RO, Mueller JG, Fosiko NG, et al. Differentiating the pathologies of cerebral malaria by postmortem parasite counts. Nat Med. 2004;10:143-5.

26. Deroost K, Lays N, Pham TT, Baci D, Van Den Eynde K, Komuta M, et al. Hemozoin induces hepatic inflammation in mice and is differentially associated with liver pathology depending on the Plasmodium strain. PLoS One. 2014;9:e113519.

27. Hansen DS, Bernard NJ, Nie CQ, Schofield L. NK cells stimulate recruitment of CXCR3 + T cells to the brain during Plasmodium berghei -mediated cerebral malaria. J Immunol. 2007;178:5779-88.

28. Giraldi-Guimardes A, Rezende-Lima M, Bruno FP, Mendez-Otero R. Treatment with bone marrow mononuclear cells induces functional recovery and decreases neurodegeneration after sensorimotor cortical ischemia in rats. Brain Res. 2009;1266:108-20. https://doi.org/10.1016/j. brainres.2009.01.062

29. Araújo IMIM, Abreu SCSC, Maron-Gutierrez T, Cruz F, Fujisaki L, Carreira H, et al. Bone marrow-derived mononuclear cell therapy in experimental pulmonary and extrapulmonary acute lung injury. Crit Care Med. 2010;38:1733-41.

30. Prota LF, Lassance RM, Maron-Gutierrez T, et al. Bone marrow mononuclear cell therapy led to alveolar-capillary membrane repair, improving lung mechanics in endotoxin-induced acute lung injury. Cell Transplant. 2010; 19(8):965-71. https://doi.org/10.3727/096368910X506845.

31. Abreu SCSC, Antunes MAMA, Maron-Gutierrez T, Cruz FFF, Carmo LGRRLG RR, Ornellas DSDS, et al. Effects of bone marrow-derived mononuclear cells on airway and lung parenchyma remodeling in a murine model of chronic allergic inflammation. Respir Physiol Neurobiol. 2011;175:153-63.

32. Maron-Gutierrez T, Castiglione RCC, Xisto DGG, Oliveira MGG, Cruz FFF, Peçanha R, et al. Bone marrow-derived mononuclear cell therapy attenuates silica-induced lung fibrosis. Eur Respir J. 2011;37:1217-25. 
33. Maron-Gutierrez T, Laffey JG, Pelosi P, Rocco PR. Cell-based therapies for the acute respiratory distress syndrome. Curr Opin Crit Care. 2014;20(1):122-31. https://doi.org/10.1097/MCC.0000000000000061.

34. Liu J, Lu X, Lou Y, et al. Xenogeneic transplantation of human placentaderived mesenchymal stem cells alleviates renal injury and reduces inflammation in a mouse model of lupus nephritis. Biomed Res Int. 2019; 2019:9370919. https://doi.org/10.1155/2019/9370919.

35. Boivin MJ, Bangirana P, Byarugaba J, Opoka RO, Idro R, Jurek AM, et al. Cognitive impairment after cerebral malaria in children: a prospective study. Pediatrics. 2007:119:e360-6.

36. Jenkins R, Omollo R, Ongecha M, Sifuna P, Othieno C, Ongeri L, et al. Prevalence of malaria parasites in adults and its determinants in malaria endemic area of Kisumu County, Kenya. Malar J. 2015;14:263.

37. de Miranda AS, Brant F, Vieira LB, Rocha NP, Vieira ÉLM, Rezende GHS, et al. A neuroprotective effect of the glutamate receptor antagonist MK801 on long-term cognitive and behavioral outcomes secondary to experimental cerebral malaria. Mol Neurobiol Molecular Neurobiology. 2017;54:7063-82.

38. Campos AC, Brant F, Miranda AS, Machado FS, Teixeira AL. Cannabidiol increases survival and promotes rescue of cognitive function in a murine model of cerebral malaria. Neuroscience. 2015;289:166-80.

39. Guha SK, Tillu R, Sood A, Patgaonkar M, Nanavaty IN, Sengupta A, et al. Single episode of mild murine malaria induces neuroinflammation, alters microglial profile, impairs adult neurogenesis, and causes deficits in social and anxiety-like behavior. Brain Behav Immun. 2014;42:123-37.

40. Pandya M, Altinay M, Malone DA, Anand A. Where in the brain is depression? Curr Psychiatry Rep. 2012;14:634-42.

41. Angelucci F, Brenè S, Mathé AA. BDNF in schizophrenia, depression and corresponding animal models. Mol Psychiatry. 2005;10:345-52.

42. Koo JW, Duman RS. IL-1 $\beta$ is an essential mediator of the antineurogenic and anhedonic effects of stress. Proc Natl Acad Sci U S A. 2008;105:751-6.

43. Cunha C, Brambilla R, Thomas KL. A simple role for BDNF in learning and memory? Front Mol Neurosci. 2010;3:1-14

44. Li YJ, Xu M, Gao ZH, Wang YQ, Yue Z, Zhang YX, et al. Alterations of serum levels of BDNF-related miRNAs in patients with depression. PLoS One. 2013; 8:1-7.

45. Xu H, Chen Z, He J, Haimanot S, Li X, Dyck L, et al. Synergetic effects of quetiapine and venlafaxine in preventing the chronic restraint stressinduced decrease in cell proliferation and BDNF expression in rat hippocampus. Hippocampus. 2006;16:551-9.

46. Bilbo SD, Barrientos RM, Eads AS, Northcutt A, Watkins LR, Rudy JW, et al. Early-life infection leads to altered BDNF and IL-1 $\beta$ mRNA expression in rat hippocampus following learning in adulthood. Brain Behav Immun. 2008;22: 451-5.

47. Huang LT. Early-life stress impacts the developing hippocampus and primes seizure occurrence: cellular, molecular, and epigenetic mechanisms. Front Mol Neurosci. 2014;7:1-15.

48. Reis PA, Comim CM, Hermani F, Silva B, Barichello T, Portella AC, et al. Cognitive dysfunction is sustained after rescue therapy in experimental cerebral malaria, and is reduced by additive antioxidant therapy. Langhorne J, editor. PLoS Pathog. 2010;6:e1000963.

49. Wang Y, Liu H, Zhang BS, Soares JC, Zhang XY. Low BDNF is associated with cognitive impairments in patients with Parkinson's disease. Park Relat Disord. 2016;29:66-71.

50. Zaletel I, Filipović D, Puškaš N. Hippocampal BDNF in physiological conditions and social isolation. Rev Neurosci. 2017:28:675-92.

51. Linares M, Marín-García P, Pérez-Benavente S, Sánchez-Nogueiro J, Puyet A, Bautista JM, et al. Brain-derived neurotrophic factor and the course of experimental cerebral malaria. Brain Res. 2013;1490:210-24.

52. Nakamura H, Sasaki Y, Sasaki M, Kataoka-Sasaki Y, Oka S, Nakazaki M, et al. Elevated brain derived neurotrophic factor levels in plasma reflect in vivo functional viability of infused mesenchymal stem cells for stroke in rats. J Neurosurg Sci. 2019;63:42-9.

53. Huang $X$, Qiang FG, Juan LW, Ding J, Wang Y, Wang H, et al. Adiposederived mesenchymal stem cells protect against CMS-induced depressionlike behaviors in mice via regulating the $\mathrm{Nrf2/HO}-1$ and TLR4/NF-KB signaling pathways. Acta Pharmacol Sin. 2020;41:612-9.

54. Dudek KA, Dion-Albert L, Lebel M, LeClair K, Labrecque S, Tuck E, et al. Molecular adaptations of the blood-brain barrier promote stress resilience vs. depression. Proc Natl Acad Sci U S A. 2020;117:3326-36.

55. Dudek KA, Dion-Albert L, Kaufmann FN, Tuck E, Lebel M, Menard C. Neurobiology of resilience in depression: immune and vascular insights from human and animal studies [published online ahead of print, 2019 Aug 17]. Eur J Neurosci. 2019. https://doi.org/10.1111/ejn.14547.

56. Menard C, Pfau ML, Hodes GE, Kana V, Wang VX, Bouchard S, et al. Social stress induces neurovascular pathology promoting depression. Nat Neurosci. 2017;20:1752-60

57. Cheng Z, Wang L, Qu M, Liang H, Li W, Li Y, et al. Mesenchymal stem cells attenuate blood- brain barrier leakage after cerebral ischemia in mice. J Neuroinflammation. 2018;15:135.

58. Reverchon F, Mortaud S, Sivoyon M, Maillet I, Laugeray A, Palomo J, et al. IL33 receptor ST2 regulates the cognitive impairments associated with experimental cerebral malaria. PLoS Pathog. 2017;13:e1006322.

59. Aigner L, Bogdahn U. TGF-beta in neural stem cells and in tumors of the central nervous system. Cell Tissue Res. 2008;331:225-41.

60. Dobolyi A, Vincze C, Pál G, Lovas G. The neuroprotective functions of transforming growth factor beta proteins. Int J Mol Sci. 2012;13:8219-58.

61. Kandasamy M, Reilmann R, Winkler J, Bogdahn U, Aigner L. Transforming growth factor-beta signaling in the neural stem cell niche: a therapeutic target for Huntington's disease. Neurol Res Int. 2011;2011:124256.

62. Wachs FP, Winner B, Couillard-Despres S, Schiller T, Aigner R, Winkler J, et al. Transforming growth factor- $\beta 1$ is a negative modulator of adult neurogenesis. J Neuropathol Exp Neurol. 2006;65:358-70.

\section{Publisher's Note}

Springer Nature remains neutral with regard to jurisdictional claims in published maps and institutional affiliations.
Ready to submit your research? Choose BMC and benefit from:
- fast, convenient online submission
- thorough peer review by experienced researchers in your field
- rapid publication on acceptance
- support for research data, including large and complex data types
- gold Open Access which fosters wider collaboration and increased citations
- maximum visibility for your research: over $100 \mathrm{M}$ website views per year
At BMC, research is always in progress.
Learn more biomedcentral.com/submissions 